\title{
Low cost rain gauge prototype for studies and monitoring of precipitation in anthropized watersheds
}

\section{Protótipo de pluviômetro de baixo custo para estudos e monitoramento da precipitação em bacias hidrográficas antropizadas}

\begin{abstract}
Bruno César dos Santos
Licenciando em Geografia pela Universidade Federal de Alfenas - UNIFAL Doutorando em Ciências da Engenharia Ambiental pela EESC/USP, Brasil bruno-unifal@hotmail.com
\end{abstract}

Mauricio Sanches Duarte Silva

Bacharel em Turismo pelo Centro Universitário Central Paulista Doutor em Ciências da Engenharia Ambiental pela EESC/USP, Brasil $\underline{\text { msan80Agmail.com }}$

Diego Narciso Buarque Pereira Engenharia Ambiental e Sanitária pela Universidade Federal de Alagoas - UFAL Doutorando em Ciências da Engenharia Ambiental pela EESC/USP, Brasil diego.narciso@usp.br

Paulo Henrique de Souza Licenciado em Geografia pela UNESP de Rio Claro/SP Doutor em Ciências da Engenharia Ambiental pela EESC/USP, Brasil phsouza31@hotmail.com

Adriano Rogério Bruno Tech Engenharia Civil habilitado em Agrimensura pela Faculdade de Engenharia de Agrimensura de Pirassununga Doutor em Zootecnia pela Universidade de São Paulo, Brasil adriano.tech@usp.br

\begin{abstract}
The acquisition of climate data is essential for understanding the environment and is fundamental in many human activities. One of the problems is the high cost of this equipment. This paper describes the development of a low-cost rain gauge prototype using the Arduino platform and presents the validation of the records against reference data. Therefore, a period of 5 days of observation was selected. Statistical methods of PEARSON and ANOVA were applied in order to verify the consistency of the prototype rainfall data with those of the USP reference station in Itirapina, SP. The results were satisfactory, and the prototype can be considered reliable since the data analysis showed equivalence with the rain gauge and the reference rain gauge.
\end{abstract}

Keywords: Climatology, Meteorology, Rain, Rainfall, Arduino.

\section{Resumo}

A aquisição de dados climáticos é de extrema necessidade para compreensão do meio ambiente, sendo fundamental em diversas atividades humanas. Um dos problemas é o alto custo destes equipamentos. Este trabalho descreve o desenvolvimento de um protótipo de pluviômetro de baixo custo utilizando a plataforma Arduino e apresenta a validação dos registros em relação a dados de referência. Para 
tanto selecionou-se um período de 5 dias de observação. Aplicou-se métodos estatísticos de PEARSON e ANOVA, afim de verificar a consistência dos dados pluviométricos do protótipo com relação aos da estação de referência da USP em Itirapina, SP. Os resultados foram satisfatórios e o protótipo pode ser considerado confiável, uma vez que a análise dos dados mostrou equivalência com o pluviômetro e o pluviógrafo de referência.

Palavras-chave: Climatologia, Meteorologia, Chuva, Pluviômetro, Arduino.

\section{INTRODUCTION}

Technological innovation to obtain climate data has been expanding in studies and research with climatology, in order to understand its dynamics and foster new tools in such studies (ZWIERS; VON STORCH, 2004, p. 674).

To Monteiro (1976), spatial analyzes have to benefit from new perspectives with an indication of factor parameters climatic, while emphasizing that must be given special attention to the temporal variations that while possible, has a direct effect to the environment and man, beyond escaping the control of the latter. Also according to Monteiro (1976), it is also worth mentioning the procedural role of climatological analysis, as well as its applications of quantitative techniques, since there are numerous statistical and interpretative limitations concerning the investigations, causes and consequences of climatic aspects in its genesis.

Local (microclimatic) climate observation can be expressed through data from key climate elements collected from weather stations on the surface distributed throughout the territory, such as radiation, temperature and relative humidity, evaporation, precipitation, atmospheric pressure, among others.

Thus, the local and regional analysis can be expressed as an articulated space-moment, in the process of intense transformation, involving multiple scales and dimensions, where there are articulations that, in turn, are not only the result of analytical cuts but also through effective realities (HAESBAERT, 2010).

Urban growth is currently one of the significant interests on this scale, as high rainfall indices cause recurrent damage to society. Thus, constant monitoring of areas considered at risks, such as urban occupations on hills, riversides and streams, is necessary along with the management for City Halls, Civil Defenses and Firefighters, for example.

Obtaining data for its collection and tabulation is one of the obstacles in the rainfall analysis in Brazil since the entities that own and manage meteorological data do not present all of the data, beyond those presented numerous failures (ZAVATTINI; BOIN, 2013).

Currently, there is high precision weather data collection equipment present in modern automatic weather stations. The problem with the technologies employed in automatic weather 
stations is their high cost, which discourages their use by public or private authorities and implies not obtaining them.

Thus, the present study aimed to develop a low-cost rain gauge prototype using an Arduino microcontroller, parts and sensors easily found on the market and to compare, through statistical analysis (daily and hourly), the data obtained from the two rain gauge prototype (USP Climatological Station in Itirapina, São Paulo State).

\section{MATERIAL AND METHODS}

\subsection{Study Area}

The study was conducted at the Climatic Station of the Center for Water Resources and Environmental Studies (CRHEA), which belongs to the School of Engineering of São Carlos, University of São Paulo (EESC/USP). The station is located in Itirapina / SP, at coordinates $22^{\circ} 10^{\prime} 12^{\prime \prime}$ (S) and 47 53 '55” (W), with an altitude of $737 \mathrm{~m}$ (Figure 1).

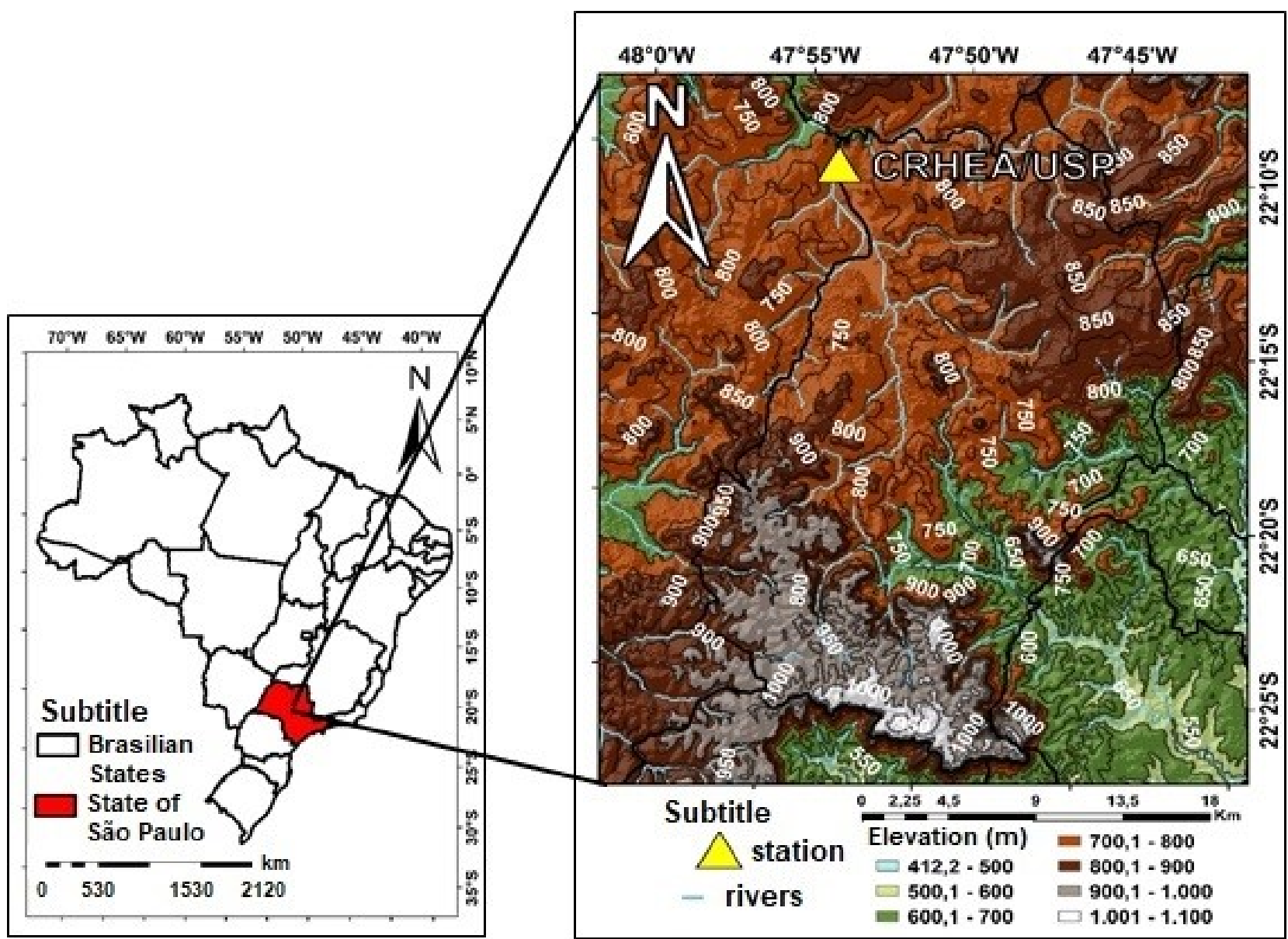

Figure 1 - Location of the study area. Climatic Station of the CRHEA/USP.

Source: Prepared by the authors. 
The climate in the region is an alternately dry and rainy regime, with summers of higher temperatures than winter and the most considerable rainfall accumulated in the summer period, called the hydrological period, with average values between 1,500 $\mathrm{mm}$ per year, and concentrating the episodes of heavy rain (SANTOS et al., 2017).

The region is placed in a plateau area to the edge of the sandstone cuestas of the Serra Geral, with altitudes ranging from 800 to $1000 \mathrm{~m}$, reaffirming the action of air masses and orographic rainfall, as well as a pattern of regional atmospheric circulation contributing together to SF and ZCAS (TOLENTINO, 1967).

The geomorphological compartment of the study region has altitudes ranging from 800 to $1000 \mathrm{~m}$ with the wettest quarter between December and February with annual rainfall ranging between 1,500 and $1,800 \mathrm{~mm}$.

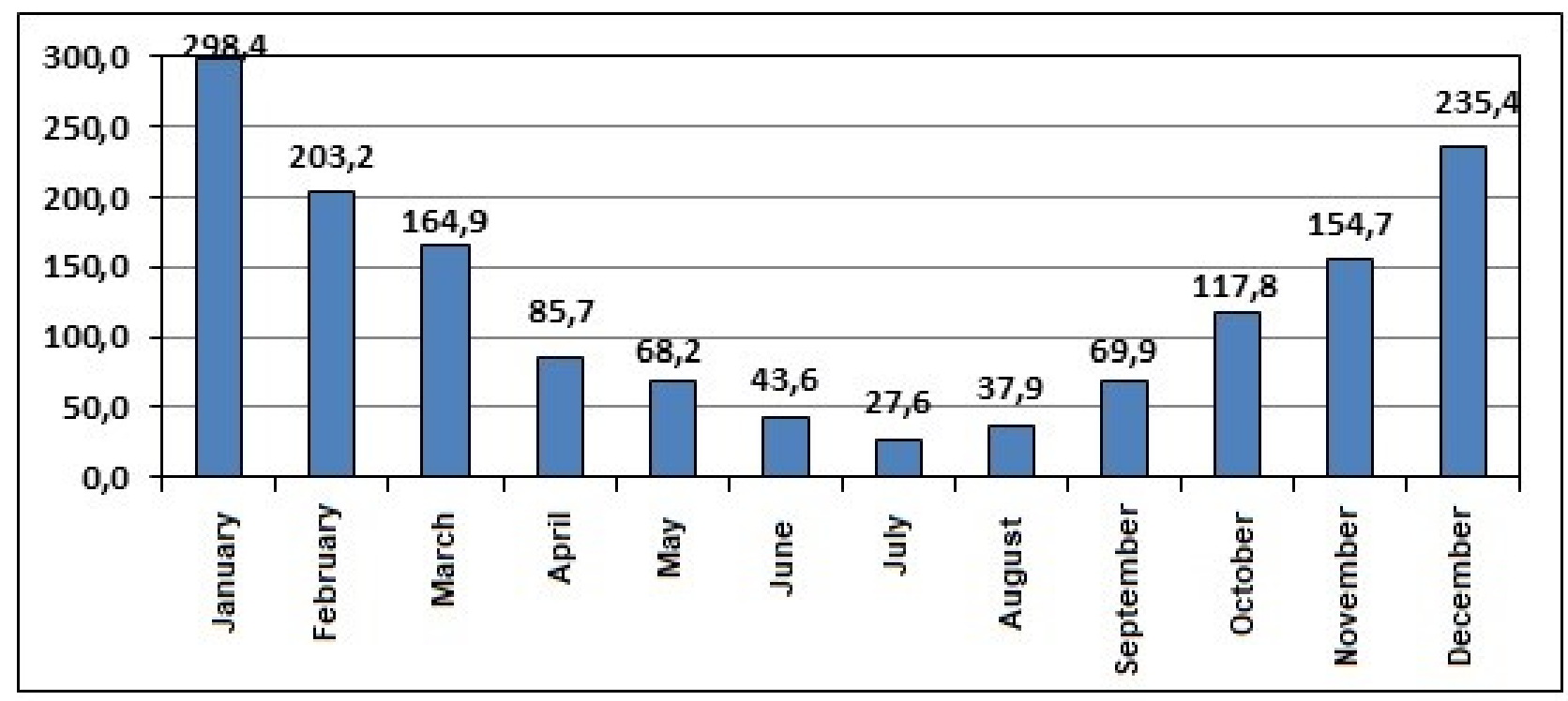

Figure 2 - Average Monthly Precipitation from 1980-2014 to Itirapina-SP region. Data source: CRHEA-USP (2017) - Accessed January 2017.

\subsection{Materials}

The USP climatology station in Itirapina has several types of equipment for collecting and recording climatological data. Thus, daily rainfall data were used in 3 equipment: an automatic rain gauge; a pluviograph; and a low-cost rain gauge on the Arduino platform. The period selected for analysis was a short-lived, high-intensity precipitation event that occurred between 18 and 22 May 2017 , under the effect of a low-pressure atmospheric system. This type of event is of particular interest to hydrological monitoring networks, especially in highly anthropized watersheds, as these (are considered to cause flooding, inundation (high-intensity rainfall and low duration). This study used information generated by the automatic rain gauge and the rain gauge, comparing them with the data of the low-cost rain gauge. 
2.2.1. Arduino platform and the low-cost rain gauge

The Arduino prototyping platform is a hardware (microcontroller) created in 2005 by a group of researchers from the Interaction Design Institute Ivrea (IDII) in Italy to enable a low cost, functional and easy to program the electronic microcontroller, streamlining and allowing studies in the most diverse areas of knowledge.

Also, the concept of free hardware has been adopted, which means that any individual can customize the device at their convenience. Thus, a circuit board was created consisting of an Atmel controller, input and output connections, all programmed via the Integrated Development Environment (IDE), using the $\mathrm{C} / \mathrm{C}++$ programming language (Figure 3).

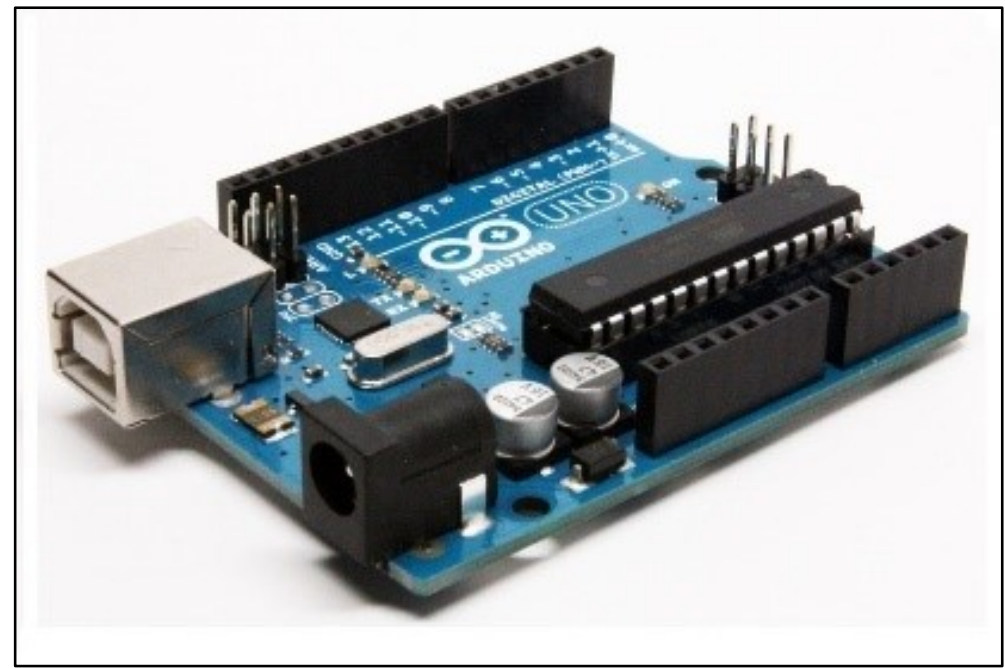

Figure 3 - Arduino Uno Platform.

Source: wwwtheengineeirgprojects.com.

The rain gauge used in this study is the Tipping Bucket type, the same type used in the CRHEA / USP automatic station. It is composed of a funnel, and aluminium cylinder with PLA (Lactic Polyacid) tilting, a thermoplastic synthetic polymer (Figure 4a / b / c), with a Reed Switch coupled magnetic wrench and a small magnet that has on and off function the sensor. It was decided to model UNO3 (Arduino board) that controls, receives, manipulates, and provides the data to the reader module / SD card recorder, which stores information rain minute to minute.

This model of rain gauge works by directing the rainwater to a triangular profile collector (tilt), divided into two symmetrical compartments concerning the transverse axis that supports it. Only one compartment receives water at a time. When the compartment fills, the container drops to the side, dispensing the liquid and recording a predetermined amount. (RETAIL-SILVA, 2000). 

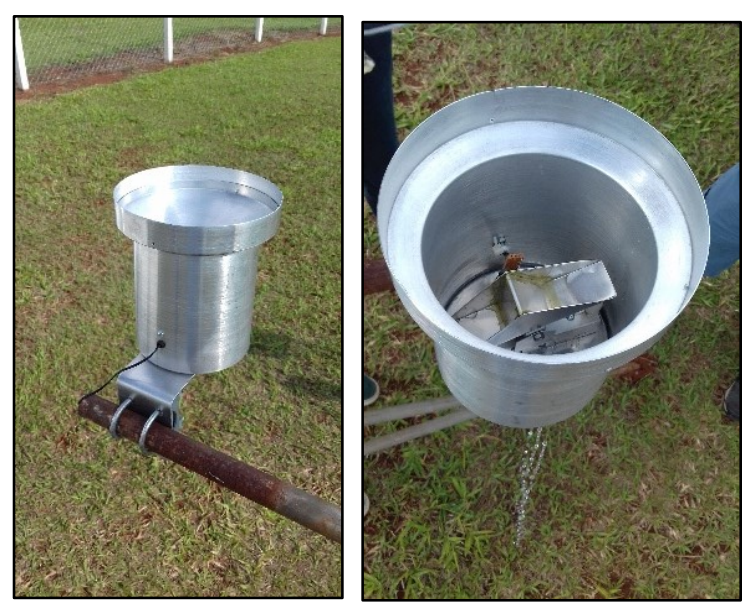

Figures 4a and 4b - Tipping Bucket Rain Gauge prototype. Source: by the authors.

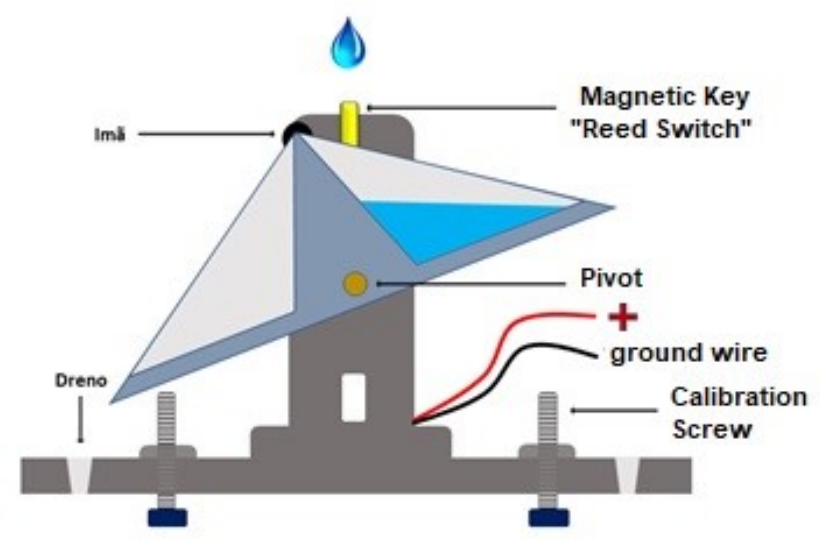

Figure 4c-Structure of the rainfall.

\subsubsection{Automatic rain gauge}

The weather station rain gauge that was used is a TR-525M model from Texas Electronics Inc (Figure 5) and works the same way as the prototype rain gauge, using a tilt that measures rainfall accumulation.

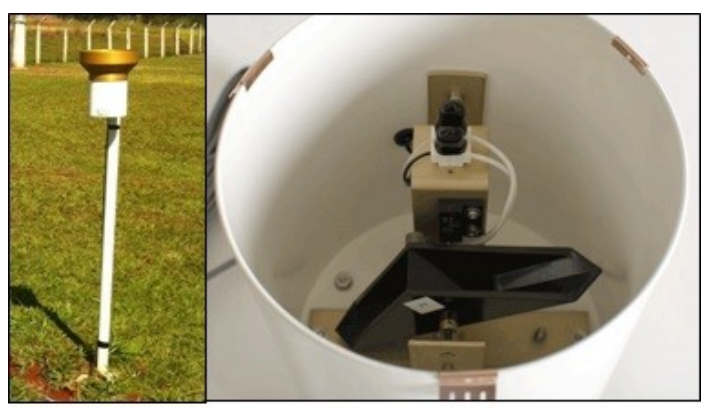

Figure 5 - Texas TR525M Rain Gauge. Source: By the authors.

\subsubsection{Rain gauge}

Pluviographs graph the total accumulated rainfall over time and are indispensable for shortterm precipitation studies as they record the intensity of the main event. Figure 6 shows the equipment used in this research. 


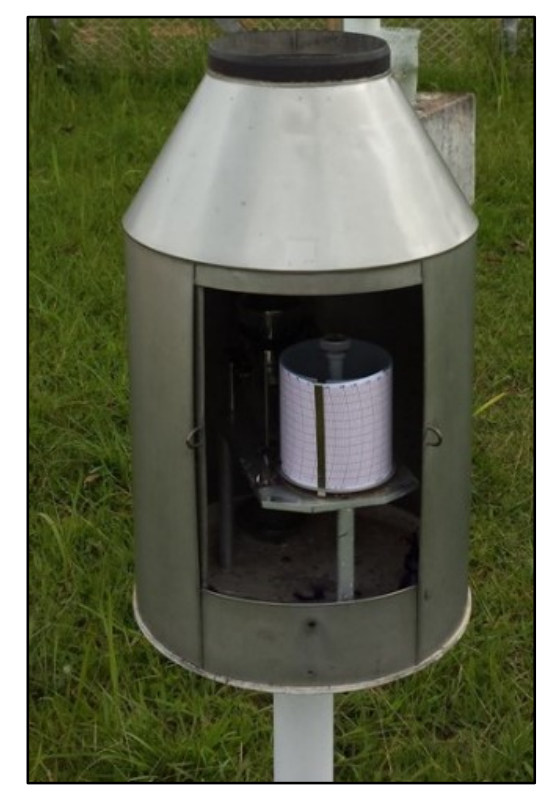

Figure 6 - Pluviographs.

Source: by the authors.

\subsection{Methodology}

Graphs and tables were prepared with rainfall records for the period, using the Microsoft Office Excel 2010 software, comparing the rainfall behaviour between the 3 data collection devices.

After tabulation, the data were compared using two statistical techniques, Pearson's correlation, for comparison between two data series, and Analysis of Variance (ANOVA), used to compare the three data series together. The determination of the coefficients $\mathrm{R}$ and $\mathrm{P}$ allows verifying the degree relation that the data series present.

\subsubsection{Pair Comparison of Station Records}

To assess the degree of reliability and correlation between the two-season records, the Pearson Correlation Coefficient (R) was used. Pearson's Coefficient estimates the correlation between two data sets and can range from -1 to +1 . Thus, the value -1 indicates a perfect negative correlation between the two data series, while the value +1 represents the perfect positive correlation. The value 0 indicates that there is no correlation between the two series.

Statistical significance must be established before the experiment is carried out, and corresponds to the risk of rejecting a true hypothesis or accepting a false hypothesis, with the threshold value of 5\%. Also, the significance of a result is referred to as the value " $p$ " ( $p$-value). When the p-value is less than or equal to 0.05 , the correlation is considered to be significantly nonzero with 95\% confidence (SPEGEL, 1993; MORENTTIN; BUSSAB, 2004). 


\subsubsection{Comparison of records from 3 stations}

In order to simultaneously compare the records of the three stations, the one-way ANOVA statistical test was used. This analysis compares the three data series in order to identify the existence of at least one difference between them.

For this, a significance level of 0.05 (95\% certainty of the result) was defined, and the pvalue was estimated to verify if the difference found is due to chance and not to the factors being studied. Moreover, if the $\mathrm{p}$-value is greater than 0.05 , it can not be said that the means of the groups are different, while if the p-value is less than 0.05 , it can be stated that the group means are different.

\section{RESULTS AND DISCUSSIONS}

From May 18 to 21, 2017, a low-pressure atmospheric system called cavado (Figure 7) moved over much of the southeastern region of Brazil, causing intense precipitation. Its physical characteristics generate a ripple in the wind flows of the atmosphere in which a significant concentration of humidity and heat is formed. Thus, to move to other areas, a thermal shock causes the air resulting in a convergence area, increasing haze formation instabilities and lines, that is, contributing to the risk of unstable weather.

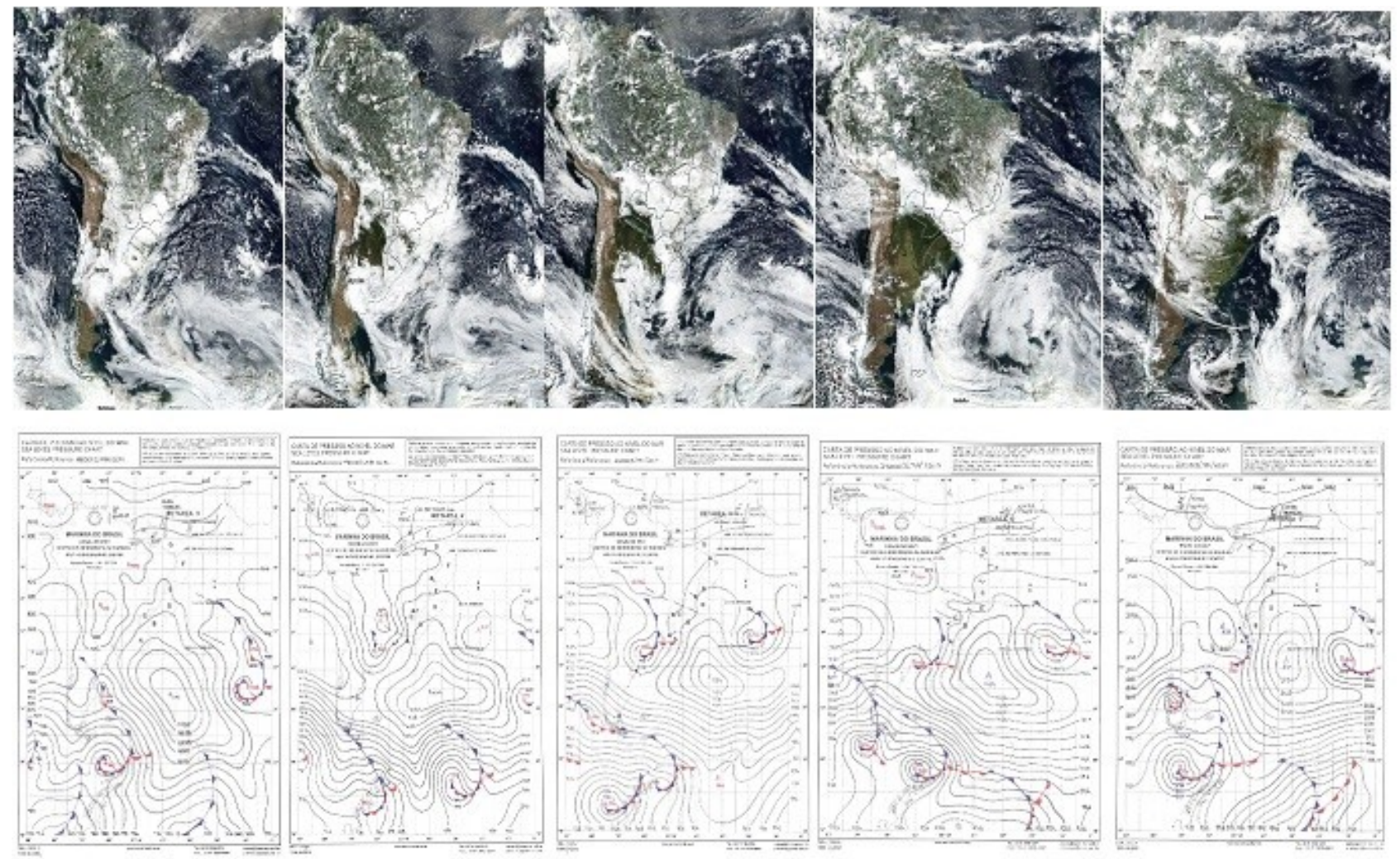

Figure 7 - Atmospheric system called "Cavado".

Source: NASA and BRAZIL's NAVY (2017). 


\subsection{Daily Data Analysis}

Figure 8 shows the distribution of daily cumulative totals by the three rain gauges, respectively.

During the period observed, the automatic rain gauge recorded $135.9 \mathrm{~mm}$ of rainfall, the experimental rain gauge (Arduino) showed $144.3 \mathrm{~mm}$, and the rain gauge recorded $154.4 \mathrm{~mm}$.

During the study period (May 18-22, 2017), rain gauges behaved similarly, i.e., with approximate daily cumulative totals (Figure 8). There are also days 19 and 21, with cumulative totals of approximately $60 \mathrm{~mm}$, which is considered an extreme event for the region under analysis (SANCHES et al., 2018).

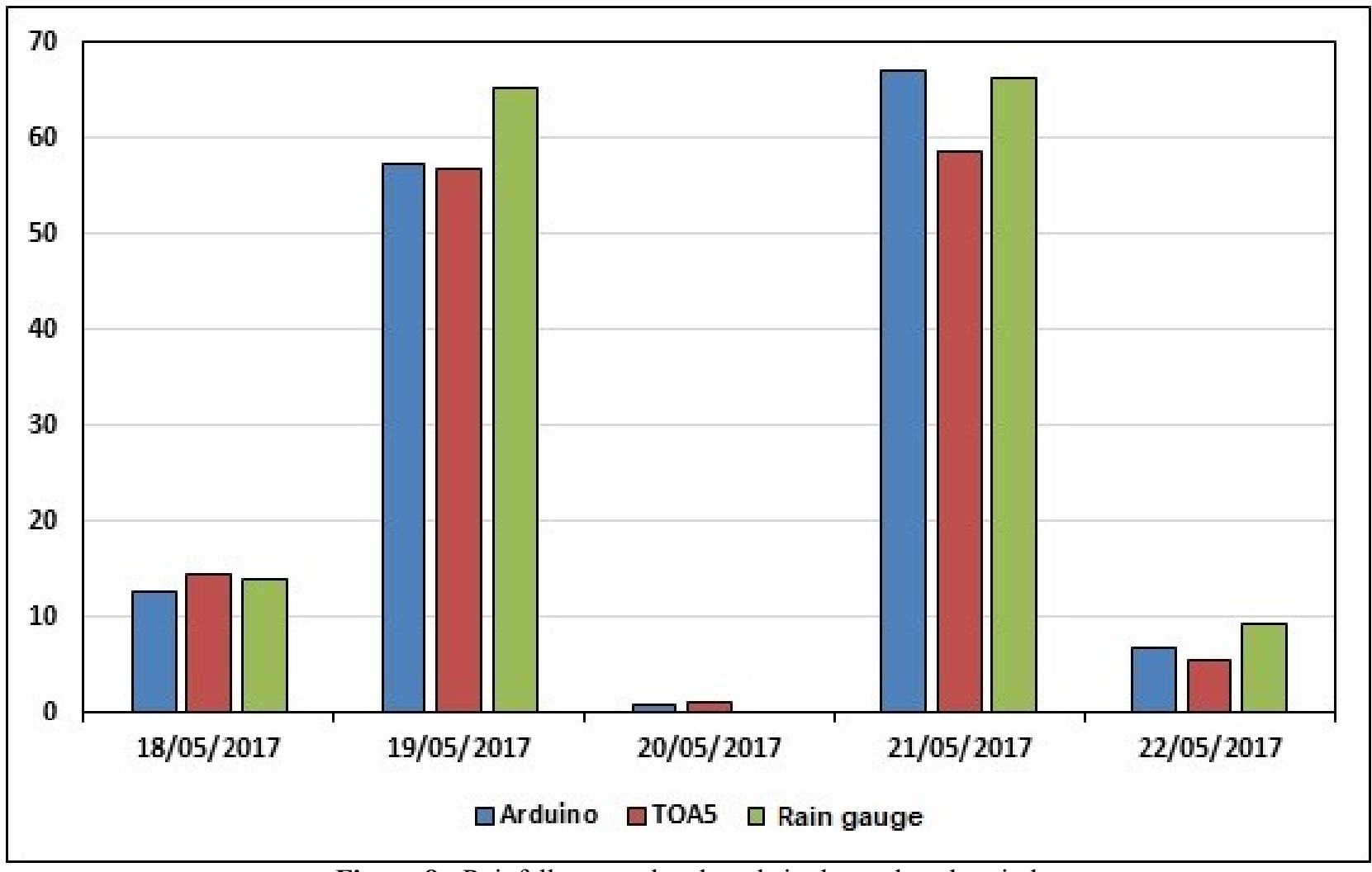

Figure 8 - Rainfall accumulated totals in the analyzed period.

\subsection{Time Data Analysis}

Given that the interest of this study is to validate the data collected in the low-cost rain gauge to monitor rainfall, an hourly analysis of the rainfall records of the analyzed equipment was performed.

For this, day 21 was selected as a representative within the analyzed period. The graphics of the precipitates values were made in a time interval of 10 , aiming to observe and compare the behaviour of each measuring equipment accurately. 
Figures 9, 10 and 11 show the hourly records of the Texas Rain Gauge, the Rain Gauge and the Arduino Rain Gauge, respectively.

It can be observed that the precipitation was concentrated between $18 \mathrm{~h}$ and $22 \mathrm{~h}$ of May 21 , when almost all the accumulated of the day occurred, besides the highest intensities recorded.

The highest intensity was recorded on the rainfall gauge $(20.5 \mathrm{~mm})$ at a time interval of 10 min, followed by the Texas gauge $(15.5 \mathrm{~mm})$ and the Arduino rain gauge $(8.5 \mathrm{~mm})$ within 10 minutes.

Given this, we obtained a radiograph of the behaviour of precipitation that enables the identification of this pattern. It was also possible to acquire the parameters that allow the development of the analysis.

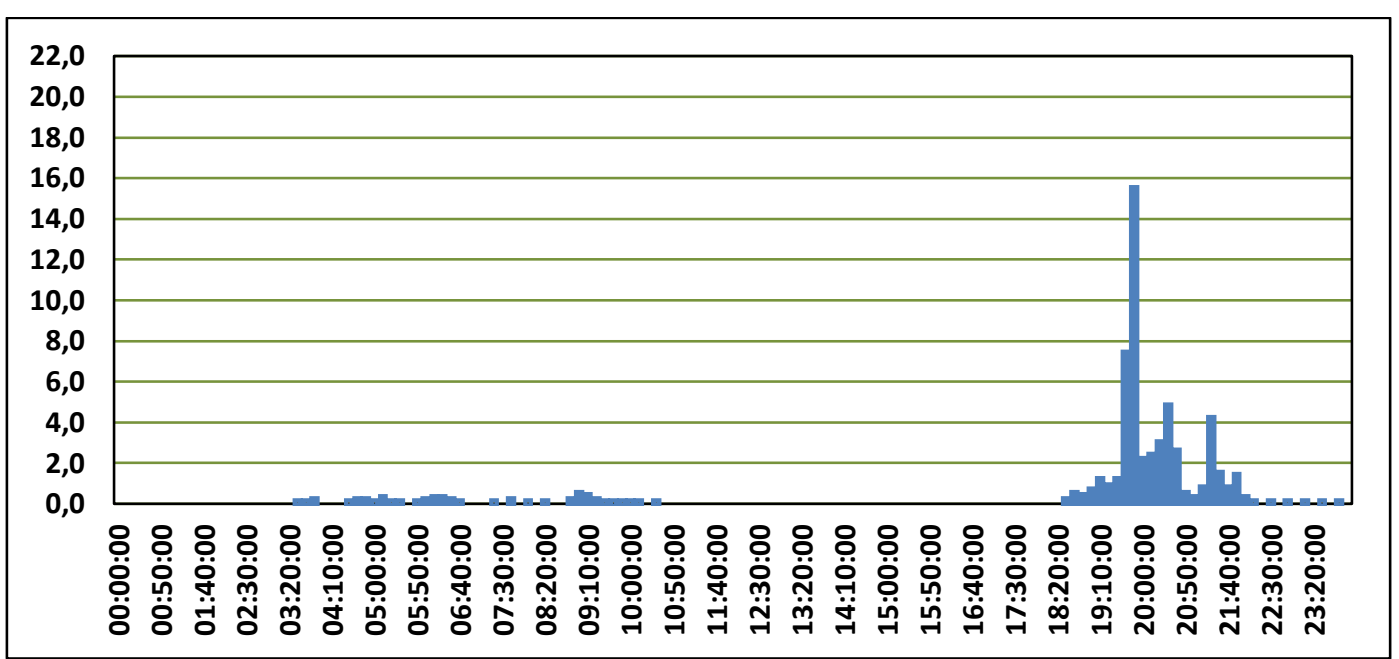

Figure 9 - Rainfall record every 10 minutes on 5/21/2017 (Texas rain gauge).

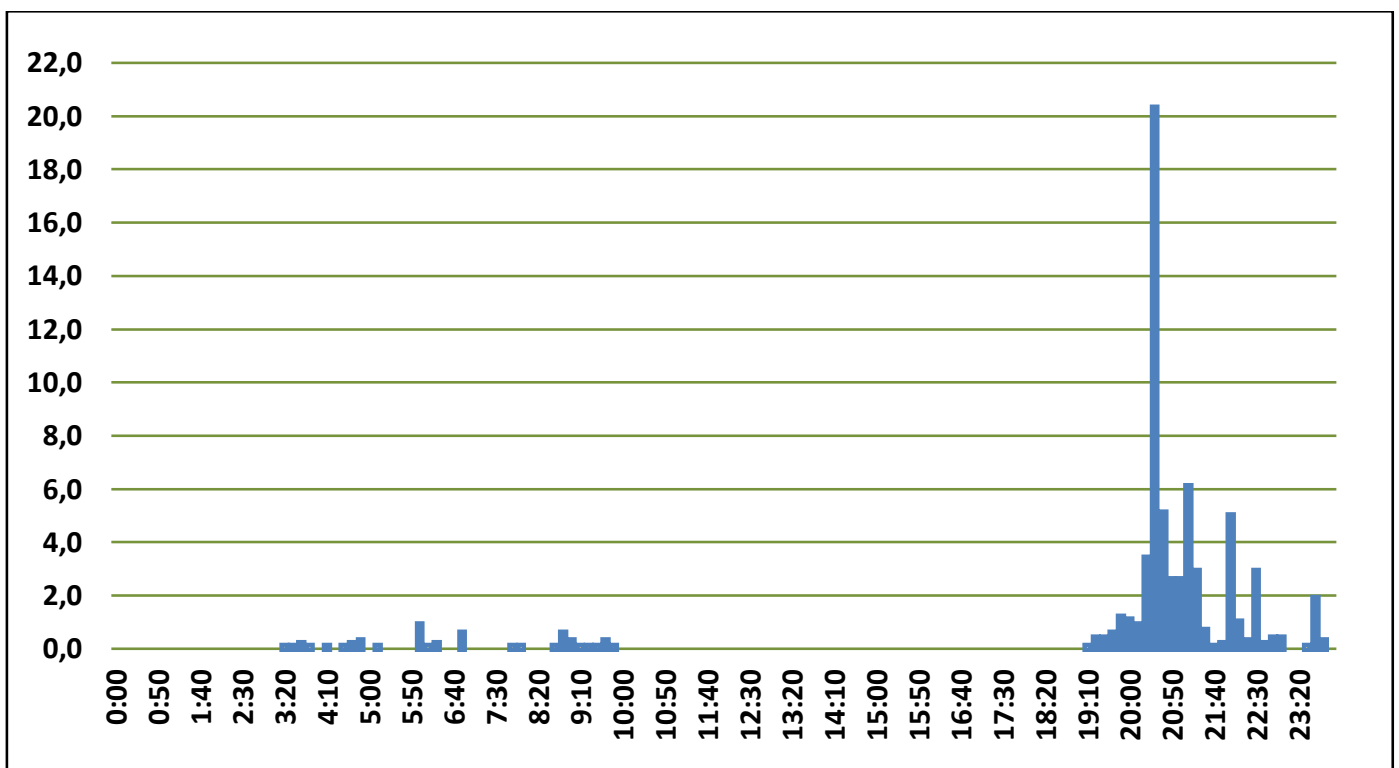

Figure 10 - Record of precipitation every 10 minutes on 5/21/2017 (rainfall). 


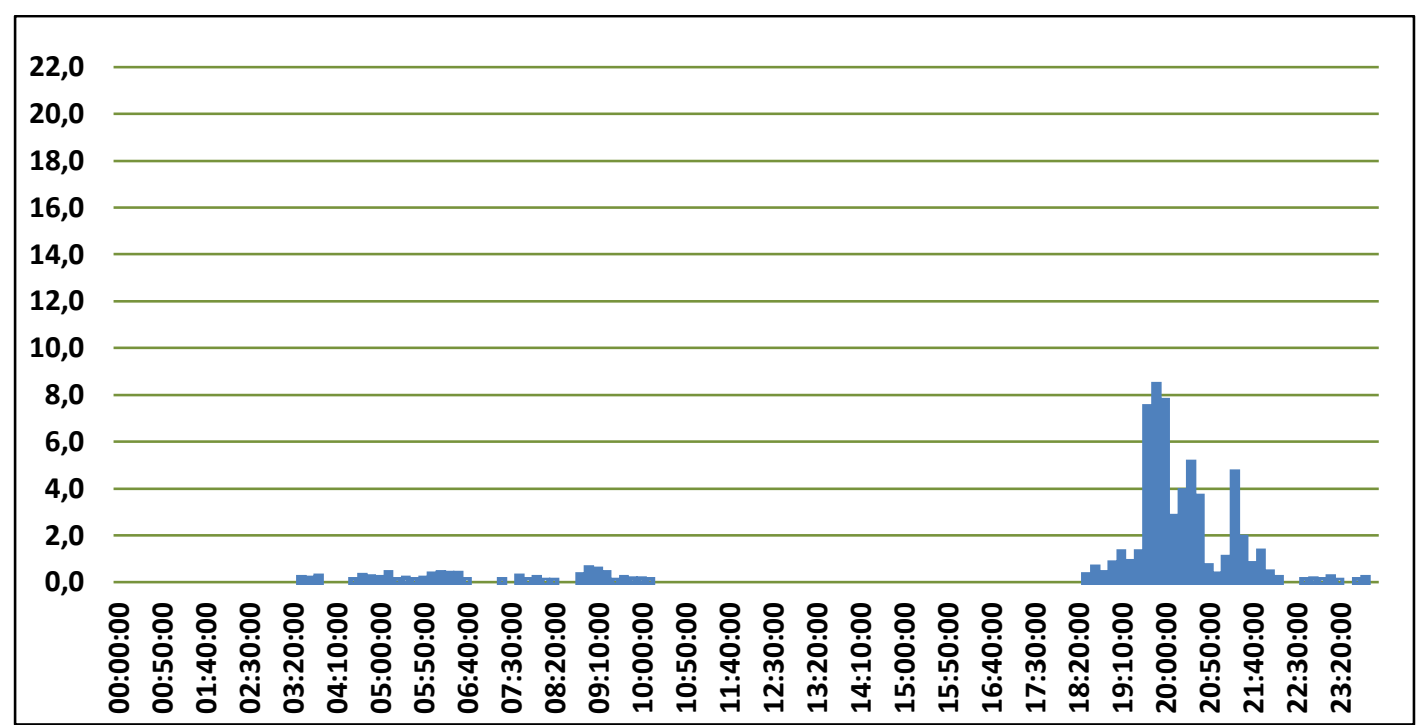

Figure 11 - Precipitation record every 10 minutes on 05/21/2017 (Arduino rain gauge).

\subsection{Data Comparison}

Comparing the data obtained between the equipment by the ANOVA variance test, allowed the significance of 0.5 , as observed in Table 1 .

Table 1: Comparison of the results of the three equipment's (ANOVA).

\begin{tabular}{|c|c|c|c|c|c|c|}
\hline \multicolumn{7}{|c|}{ RESUME } \\
\hline Group & Score & Sum & Average & Variance & & \\
\hline Column 1 & 145 & 66,2 & 0,456552 & 3,638169 & & \\
\hline Column 2 & 145 & 58,5 & 0,403448 & 2,432141 & & \\
\hline Column 3 & 145 & 61,92 & 0,427034 & 1,785538 & & \\
\hline \multicolumn{7}{|c|}{ ANOVA } \\
\hline Source of Variation & $S Q$ & $g l$ & $M Q$ & $F$ & value-P & $F$ critical \\
\hline Between Groups & 0,205298 & 2 & 0,102649 & 0,0392 & 0,961562 & 3,016603 \\
\hline Within Groups & 1131,242 & 432 & 2,618616 & & & \\
\hline Total & 1131,447 & \multicolumn{2}{|c|}{434} & & & \\
\hline
\end{tabular}

The information generated in the analysis of variance is the degrees of freedom, the sum of squares, the mean square, the F statistic and the -P-value.

The degrees of freedom are calculated based on the number of stations and the total number of occurrences. Sum of squares measured data variation. The total of squares measured the total variation in the data, the sum of squares of the treatments obtained the variation between seasons and the sum of the squares of the residuals showed the variation within each series, that is, it demonstrated the variation of the series between each station. Using the value obtained from the source of variation $\mathrm{P}=0.961$, it can be stated that the series does not have significant variance, that is, they present excellent correlation. In the evaluation of the correlation between the daily data obtained by the 
rainfall and the Arduino, the value of $\mathrm{R}=0.99(\mathrm{p}=0.005)$ was obtained, indicating an excellent correlation between the two data sets.

For time data, the Arduino rain gauge results showed a good affinity with the Texas rain gauge records and low affinity with the results of the rain gauge.

The analyzes indicate a high correlation between Texas and Arduino rain gauges and a low correlation between these and the rain gauge. This fact may be associated with differences in the collection mechanisms (as mentioned in the methodology) (Table 2).

Table 2 - Pearson's correlation coefficient (r) for the hourly scale.

\begin{tabular}{ccc}
\hline Pearson's coeficiente r (value of $\mathrm{p})$ & Automatic & Arduino \\
\hline Rain gauge & $0,24\left(4,4 \times 10^{-3}\right)$ & $0,36\left(1,1 \times 10^{-5}\right)$ \\
Arduino & $0,87(0,0)$ & \\
\hline
\end{tabular}

\section{CONCLUSION}

All of the equipment showed similarity in information, especially if we consider more prolonged periods, when the comparison occurs in shorter periods, for example, every 10 minutes or even 1 and 1 minute the difference between the data begins to widen and the correlations to decrease, one possible explanation would be the physicochemical differences between the equipment material that despite collecting similar data are made of different compounds, besides having different measurements. Nevertheless, given the results found and the importance of constant monitoring and follow-up of precipitation events, especially in highly anthropized urban areas, the positive potential of using the low-cost alternative system has been demonstrated.

It is important to note that the intention of the study strictly offers an alternative to the high prices charged in the market and traditional brands and do not discuss the quality of the equipment. Even because, it is evident that the quality of the professional models that have decades of engineering applied to the evolution of the design is superior to our modestly assembled prototypes in the core lab.

The problem lies in the lack of access to this type of technology and series of later limitations that society and public or private power have, as essential data on the local climate dynamics are ignored in the development, conduct and proposition of policies, proposals, hat aim to integrate more sustainably our relations with the environment in which we live.

\section{REFERENCES}


HAESBAERT, R. H. C. Regional-global: dilemas da região e da regionalização na geografia contemporânea. Rio de Janeiro: Bertrand Brasil, 2010. 210p.

MONTEIRO, C. A. F. O Clima e a organização do espaço no estado de São Paulo problemas e perspectivas. São Paulo: IGEOG/USP, n. 28, 1976. (Série “Teses e Monografias”).

SANCHES, R. G; NEVES, G. Z. F.; SANTOS, B. C.; SILVA, M. S. D.; PEREIRA, D. N. B.; TECH, A. R. B. Intense Rainfall in São Carlos/SP: Determination of Threshold Values Using Climate Indices and Their Spatio-Temporal Repercussion. American Journal of Climate Change, v. 7, p. $388,2018$.

SANTOS, B. C; SOUZA, P. H.; VECCHIA, F. A. S. A caracterização da precipitação do ano hidrológico de 2013-2014 na região de São Carlos/SP e sua repercussão no espaço geográfico. Revista Brasileira de Climatologia, v. 21, p. 135-152, 2017.

VAREJÃO-SILVA, M. A. Meteorologia e climatologia. Brasília: INMET, Stilo, 2000. 463p.

ZAVATTINI, J. A.; BOIN, M. N. Climatologia geográfica: teoria e prática de pesquisa. Campinas: Alínea, 2013. 152p.

ZWIERS, F. W.; VON STORCH, H. On the role of statistics in climate research. International Journal of Climatology, v. 24, n. 6, p. 665-680, 2004. 